medRxiv preprint doi: https://doi.org/10.1101/2021.03.20.21253838; this version posted August 16, 2021. The copyright holder for this preprint (which was not certified by peer review) is the author/funder, who has granted medRxiv a license to display the preprint in It is made available under a CC-BY-NC-ND 4.0 International license

Running title: The $p$-factor in childhood

\title{
The General Psychopathology Factor from Early to Middle Childhood: Longitudinal Genetic and Risk Analyses
}

\author{
Reut Avinun, Ariel Knafo-Noam, and Salomon Israel
}

Department of Psychology, The Hebrew University of Jerusalem, Israel 
medRxiv preprint doi: https://doi.org/10.1101/2021.03.20.21253838; this version posted August 16, 2021. The copyright holder for this preprint (which was not certified by peer review) is the author/funder, who has granted medRxiv a license to display the preprint in

\section{Abstract}

2 Accumulating research suggests the structure of psychopathology is best represented

3 by continuous higher-order dimensions, including a general dimension, $p$-factor, and

4 more specific dimensions, e.g., residualized externalizing and internalizing factors.

5 Here, we aimed to 1) replicate $p$ in early childhood; 2) externally validate the factors

6 with key constructs of psychological functioning; 3) examine stability and change of

7 genetic and environmental influences on the psychopathology factors from early- to

8 mid-childhood; 4) examine the factors' predictive utility; and 5) test whether the

9 factors can be predicted by early life measures (e.g., neonatal complications). The Longitudinal Israeli Study of Twins from age 3 to 9 was used for the analyses.

Mothers reported on developmental problems, pregnancy and neonatal conditions, and filled in questionnaires on each twin's externalizing and internalizing symptoms.

Cognitive ability was assessed in the lab at age 6.5 and personality traits, self-esteem, and life satisfaction were self-reported by the twins at ages 11-13. A bifactor model that included $p$ and externalizing and internalizing factors fit the data best and associations between $p$, cognitive ability, and personality were replicated. Longitudinal twin analyses indicated that $p$ is highly heritable (64-73\%) with a substantial proportion of the genetic influences stable from age 3. The residualized internalizing and externalizing factors were also highly heritable. Higher $p$ predicted developmental problems at age 8-9 and lower self-esteem at age 11. Early life measures were not strongly associated with psychopathology. Our results show that $p$ is discernible in early childhood, highly heritable, and prospectively associated with negative outcomes. 
medRxiv preprint doi: https://doi.org/10.1101/2021.03.20.21253838; this version posted August 16, 2021. The copyright holder for this preprint (which was not certified by peer review) is the author/funder, who has granted medRxiv a license to display the preprint in It is made available under a CC-BY-NC-ND 4.0 International license .

25 Keywords: Psychopathology; childhood; general psychopathology factor; $p$-factor;

26

27

\section{General Scientific Summary}

The general psychopathology factor is discernible in early childhood, highly heritable, with genetic influences contributing to both stability and change, and prospectively associated with developmental problems and lower self-esteem. Early life measures, such as birth complications or hospitalizations during the first year of life, were not strong predictors of the general psychopathology factor or the residualized externalizing and internalizing factors. 
medRxiv preprint doi: https://doi.org/10.1101/2021.03.20.21253838; this version posted August 16, 2021. The copyright holder for this preprint (which was not certified by peer review) is the author/funder, who has granted medRxiv a license to display the preprint in It is made available under a CC-BY-NC-ND 4.0 International license .

37 Comorbidity of psychopathology is prevalent. About $40 \%$ of individuals with one 38 class of disorders (e.g., mood, anxiety, substance abuse) are likely to be diagnosed 39 with another (Merikangas et al., 2010; Newman, Moffitt, Caspi, \& Silva, 1998). As a result of this co-occurrence, instead of discrete mental disorders, researchers have begun to conceptualize the structure of psychopathology as consisting of broad transdiagnostic dimensions, including externalizing (e.g., hyperactivity and antisocial behavior), internalizing (e.g., depression and anxiety), and thought disorders (schizophrenia and obsessive compulsive disorder). Accumulating evidence has suggested that in addition to specific factors, such as externalizing and internalizing, a general psychopathology factor, often called $p$ (Caspi et al., 2014), is also needed to represent the structure of psychopathology (Lahey et al., 2012). The $p$-factor captures shared variation across most, if not all, types of psychopathology and is thought to represent a general liability for mental disorders, as well as their persistence and severity (Caspi \& Moffitt, 2018).

The $p$-factor has been identified in various age groups, from preschoolers to adolescents and adults; in clinical and general population samples; in different countries; and using different methods and measures (e.g., Caspi et al., 2014; Gomez, Stavropoulos, Vance, \& Griffiths, 2019; Hyland et al., 2018; Laceulle, Chung, Vollebergh, \& Ormel, 2020; Olino, Dougherty, Bufferd, Carlson, \& Klein, 2014; Patalay et al., 2015; Snyder, Young, \& Hankin, 2017). To characterize and validate the $p$-factor, researchers have examined its association with broadly informative indicators of psychological functioning such as personality traits and cognitive ability. In early and middle adulthood, the $p$-factor has been found to correlate positively with neuroticism and negatively with agreeableness and conscientiousness (e.g., Avinun, Romer, \& Israel, 2020; Caspi et al., 2014; Etkin, Mezquita, López-Fernández, Ortet, 
medRxiv preprint doi: https://doi.org/10.1101/2021.03.20.21253838; this version posted August 16, 2021. The copyright holder for this preprint (which was not certified by peer review) is the author/funder, who has granted medRxiv a license to display the preprint in It is made available under a CC-BY-NC-ND 4.0 International license .

$62 \&$ Ibáñez, 2020). Correlations between the $p$-factor and measures relating to cognitive 63 ability and executive function have been found to be negative in middle childhood 64 (Martel et al., 2017), early-adolescence (Patalay et al., 2015), and adulthood (Caspi et 65 al., 2014).

Further supporting the $p$-factor's reliability are genetic studies showing that the $p$-factor is genetically influenced, i.e., not only explained by noise and measurement error, and that these genetic influences are relatively stable across time (Allegrini et al., 2020; Riglin et al., 2019; Selzam, Coleman, Caspi, Moffitt, \& Plomin, 2018). A longitudinal twin analysis from childhood (age 7 years) to adolescence (age 16 years), has shown that the $p$-factor is substantially heritable (50-60\%) across ages and that the genetic component is relatively stable, so that the genetic influence at age 7 accounts for most of the genetic variance in later ages (Allegrini et al., 2020). Notably, to our knowledge, the latter study is the only study to date that employed a longitudinal twin design to examine change and stability in the genetic and environmental effects on the $p$-factor, and no study has examined the specific/residualized factors (e.g., externalizing and internalizing). Additional developmental research is therefore warranted, especially during early life when executive functions, which are significantly linked to externalizing and internalizing symptoms (Hughes \& Ensor, 2011), rapidly develop.

The $p$-factor has also been shown to predict negative outcomes (e.g., Blanco et al., 2019; Lahey et al., 2015). For example, estimates of the $p$-factor in middle childhood and early adolescence predict psychiatric diagnoses (anxiety, depression, and alcohol and drug use disorders), use of anxiolytics and antidepressants, school failure, and court convictions in adolescence (Pettersson, Lahey, Larsson, \& Lichtenstein, 2018). Taken together, the above findings support the reliability and 
medRxiv preprint doi: https://doi.org/10.1101/2021.03.20.21253838; this version posted August 16, 2021. The copyright holder for this preprint (which was not certified by peer review) is the author/funder, who has granted medRxiv a license to display the preprint in It is made available under a CC-BY-NC-ND 4.0 International license .

87

validity of the $p$-factor as a common variance that captures an inherent and general risk for psychopathology.

Although the shared variance across mental disorders is a robust and replicable finding, the mechanisms that underlie this general risk are less clear and longitudinal studies are scarce. While various candidates likely play a role in the etiology of the $p$ factor, of special interest perhaps, are those that are present at or around birth, as previous studies suggest that the $p$-factor can be found early in development, in children as young as 4 years old (Morales et al., 2021). For example, the link between the $p$-factor in adulthood and childhood socioeconomic status (SES) has been examined, as studies have shown that children raised in families with low SES show increased risk for psychopathology (Peverill et al., 2020), particularly externalizing behaviors. Interestingly, at least one study has found the correlation between the $p$ factor and childhood SES to be weak (Caspi et al., 2014).

Pregnancy, obstetric, and neonatal complications have previously been identified as increasing risk for poorer mental health and/or poorer cognitive function (De Mola, De França, de Avila Quevedo, \& Horta, 2014; Ehrenstein et al., 2009; Hamlyn, Duhig, McGrath, \& Scott, 2013; Van Lieshout \& Voruganti, 2008). For example, Chiorean and colleagues (2020) found that children admitted to neonatal/special care units at birth were more likely to develop a psychiatric disorder in adolescence. Similarly, preterm birth has been associated with increased risk of psychiatric hospitalizations in young adulthood (Nosarti et al., 2012), and pregnancy/birth complications (e.g., prenatal bleeding, hypertension and diabetes, breech birth, and instrument delivery) have been associated with externalizing problems at age 11 (Liu, Raine, Wuerker, Venables, \& Mednick, 2009). Because 
medRxiv preprint doi: https://doi.org/10.1101/2021.03.20.21253838; this version posted August 16, 2021. The copyright holder for this preprint (which was not certified by peer review) is the author/funder, who has granted medRxiv a license to display the preprint in It is made available under a CC-BY-NC-ND 4.0 International license

111

these factors are not necessarily specific to any particular psychopathology, they may serve as transdiagnostic risk factors.

In the current study, we test the replicability of the general psychopathology factor finding from early to middle childhood (e.g., Hankin et al., 2017; Olino et al., 2014), on a longitudinal sample of twins followed from age 3 to age 9. Next, we evaluate the external validity of $p$ and the specific/residualized externalizing and internalizing factors by testing for associations with personality traits and cognitive ability, and examine if/how these associations change during development. Following these analyses, we conduct a genetically informed longitudinal analysis from early to middle childhood to examine stability and change of the genetic and environmental influences on the psychopathology factors. This analysis can provide further support for the reliability of the factors by showing their stability across time. We next tested the predictive value of the three factors in the context of developmental problems at age 8-9 (whether the child suffers from e.g., stammering, speech delay, and emotional, social, or communication problems), self-esteem at age 11, and life satisfaction at age 13. Finally, we conducted exploratory analyses to examine whether measures that can be assessed early in the child's life, such as SES at age 3 and pregnancy, obstetric, and neonatal complications, can predict the psychopathology factors. We hypothesized that risk measures, such as low SES, low birth weight and complications of pregnancy (e.g., rubella, RH mismatch, bleeding during pregnancy or miscarriage risk, and preeclampsia), will be associated with higher scores of the psychopathology factors.

\section{Methods}

\section{Participants}


medRxiv preprint doi: https://doi.org/10.1101/2021.03.20.21253838; this version posted August 16, 2021. The copyright holder for this preprint (which was not certified by peer review) is the author/funder, who has granted medRxiv a license to display the preprint in It is made available under a CC-BY-NC-ND 4.0 International license .

136 Families in this study were participants in the Longitudinal Israeli Study of Twins 137 (LIST), a study of social development, in which parents of all Hebrew-speaking 138 families of twins born in Israel during 2004-2005 were invited to participate (Avinun 139 \& Knafo, 2013; Vertsberger, Abramson, \& Knafo-Noam, 2019). At each wave the 140 experimental protocol was approved by the ethics committee of either the university or the local hospital, and informed consent was obtained from all participating parents. Mothers were asked to complete questionnaires regarding their pregnancy (only age 3 and 5), demographic details, and children's development, when the twins were $3,5,6.5$, and $8-9$ years old. Data for this study was available for 2,770 children at age $3(\mathrm{M}=3.16$ years, $\mathrm{SD}=.26 ; 50.3 \%$ males; $582 \mathrm{MZ}$ [monozygotic], 2,164 DZ [dizygotic], and 24 of unknown zygosity), 1,908 at age $5(\mathrm{M}=5.13$ years, $\mathrm{SD}=.14$; $51 \%$ males; $370 \mathrm{MZ}, 1,518 \mathrm{DZ}$, and 20 of unknown zygosity), 1,020 at age 6.5 (M=6.57 years, $\mathrm{SD}=.30 ; 50 \%$ males; $285 \mathrm{MZ}, 729 \mathrm{DZ}$, and 6 of unknown zygosity), and 973 at age 8-9 $(M=9.01$ years, $S D=.52 ; 48.7 \%$ males; $260 \mathrm{MZ}, 699 \mathrm{DZ}$, and 14 of 150 unknown zygosity). Due to design and budgetary constraints, at ages 6.5 and 8-9 only 151 a small number of opposite-sex DZ twins and only families with which it was possible 152 to schedule an in-person experiment were recruited. Twins' zygosity was determined based on either a DNA analysis or a parental questionnaire of physical similarity, which has been shown to be in 95\% agreement with DNA information (Goldsmith, 155 1991).

About $25 \%$ of the age 3 families did not participate in later waves, a comparison 157 of this group of families to families that did participate in at least one more wave is 158 shown in Supporting Table 1. There were no significant differences in the means of 159 SES or mother reports of children's psychopathology (the assessment of these 160 measures is detailed below. Comparisons were made in Mplus version 7, using the 
medRxiv preprint doi: https://doi.org/10.1101/2021.03.20.21253838; this version posted August 16, 2021. The copyright holder for this preprint (which was not certified by peer review) is the author/funder, who has granted medRxiv a license to display the preprint in It is made available under a CC-BY-NC-ND 4.0 International license.

161

162

163

164

165

166

167

168

type=complex with the 'cluster' option, to account for the dependent structure of the data).

\section{Measures}

\section{Psychopathology}

Similar to a previous study in childhood that relied on symptom-level, instead of disorder-level, scores (Patalay et al., 2015), items from 2 different questionnaires were used for the assessment of psychopathology. Internalizing symptoms were assessed in the four waves by mothers' ratings of 5 items from the emotional symptoms subscale of the Strengths and Difficulties Questionnaire (SDQ; Goodman, 1997) and 5 items from the negative emotionality subscale of the Emotionality, Activity and Sociability Temperament Survey (Buss \& Plomin, 1984). Ratings were given on a 3-point scale ranging from 0 (not true/rare) to 2 (very true/often) or on a 5-point scale ranging from 1 (does not characterize at all) to 5 (highly characterizes), respectively. Externalizing symptoms were assessed in the four waves by mothers' ratings of 10 items from the SDQ (Goodman, 1997). The 10 items were taken from the hyperactivity subscale (5 items) and the conduct problems subscale (5 items).

\section{Socioeconomic status}

SES was calculated from mother reports when children were 3 based on the number of rooms/number of residents' ratio, income (reported on a scale from 1-considerably below average to 5-considerably above average, with 3 representing the national average), and mother's years of education. These variables were standardized and then averaged (e.g., Avinun \& Knafo-Noam, 2017). 
medRxiv preprint doi: https://doi.org/10.1101/2021.03.20.21253838; this version posted August 16, 2021. The copyright holder for this preprint (which was not certified by peer review) is the author/funder, who has granted medRxiv a license to display the preprint in It is made available under a CC-BY-NC-ND 4.0 International license .

186

187 When the twins were 3 and 5, mothers provided details regarding complications

188

189

190

191

192

193

\section{Pregnancy and delivery information} during pregnancy and/or delivery (e.g., rubella, $\mathrm{RH}$ mismatch, bleeding during pregnancy or miscarriage risk, preeclampsia, gestational diabetes, high risk pregnancy/bed rest, hospitalizations, umbilical cord prolapse, breech birth, assisted delivery, and placental abruption) and neonatal problems of each twin (neonatal hepatitis, neonatal diabetes, and being in an incubator). Complications during pregnancy/delivery and neonatal problems were summary scores of all relevant yes/no questions. Additional information that we included in our analyses: total weeks of pregnancy, Apgar scores of each twin 1- and 5-minutes after birth, whether each twin was hospitalized in the first year of life or afterwards, and breastfeeding (whether they breastfed each twin). Notably, maternal recall 4 to 6 years later regarding perinatal events has been found to be $89 \%$ accurate in comparison with hospital records (Githens, Glass, Sloan, \& Entman, 1993).

\section{Developmental problems}

At all ages (i.e., 3, 5, 6.5, and 8-9) mothers were asked whether either twin suffered from developmental problems (e.g., stammering, speech delay, emotional, social, or communication problems, hypotonia or hypertonia, difficulty with gross/fine motor skills, behavior problems, hearing/vision impairment, attention/hyperactivity problems, eating problems, and wetting/toilet training problems). This was coded as 0 or 1 .

\section{Cognitive ability}


medRxiv preprint doi: https://doi.org/10.1101/2021.03.20.21253838; this version posted August 16, 2021. The copyright holder for this preprint (which was not certified by peer review) is the author/funder, who has granted medRxiv a license to display the preprint in It is made available under a CC-BY-NC-ND 4.0 International license

The Block Design (visual processing) and the Vocabulary (crystallized intelligence) subsets of the Wechsler Intelligence Scale for Children-IV (WISC-IV; Lerner \& Miller, 1978) were used to assess cognitive ability. The Block design subset includes 14 items and participants are asked to assemble blocks under a time limit, based on a pattern that is shown by the examiner. The Block design is scored based on accuracy and time. The vocabulary subset includes 37 items and participants are asked to explain a word using their own words. Scores reflect the accuracy of their definition. A mean of the two subsets' scores was used as a cognitive ability score. Both subsets were administered at the lab or at the children's homes when the twins were 6.5 years old.

\section{Personality}

At age 11 the twins were asked to fill in the Big Five Inventory (BFI) questionnaire (John, Donahue, \& Kentle, 1991) either online or by hand. The BFI includes 44 items (e.g., "I am sometimes rude to others") used to assess individual differences along the five-factor model of personality: neuroticism, extraversion, openness, conscientiousness, and agreeableness. Each scale was measured using 8-9 items, and an average requiring at least 5 non-missing items was calculated for each trait. Data was available for 1,349 children.

\section{Self-Esteem}

At age 11 the twins were asked to fill in the Rosenberg Self-Esteem Scale (Rosenberg, 1965) either online or by hand. The 10 items of the questionnaire (e.g., "I wish I could have more respect for myself") were summed to create a self-esteem score. Data was available for 1,106 children. 
medRxiv preprint doi: https://doi.org/10.1101/2021.03.20.21253838; this version posted August 16, 2021. The copyright holder for this preprint (which was not certified by peer review) is the author/funder, who has granted medRxiv a license to display the preprint in It is made available under a CC-BY-NC-ND 4.0 International license .

Life satisfaction

237 At age 13 the twins were asked to fill in 4 items ("my life is going well", "my life is 238 just right", "I have a good life", and " I have what I want in life") taken from the 239 Student's Life Satisfaction Scale (Huebner, 1991). A mean of the 4 items (with a minimum of 3 items) was used as a life satisfaction score. Data was available for 703 children.

\section{Statistical analyses}

\section{Replication of the p-factor/Verifying the bifactor model}

245 The same 20 items representing internalizing and externalizing symptoms were used 246 for the factor analyses at each age, to allow developmental analyses and unambiguous comparisons across waves (as previously done, e.g., Murray, Eisner, \& Ribeaud, 2016). The items were defined as categorical, which is needed in Mplus to indicate that they should be treated as ordinal variables in the model. As previously done 250 (Avinun et al., 2020; Caspi et al., 2014; Romer et al., 2018), we used confirmatory factor analysis to fit three structural models: 1) A bifactor/hierarchical model, which consists of a $p$-factor that loads on all items, and two additional factors that are allowed to correlate, each loading separately on either internalizing or externalizing symptom items; 2) A one factor model, which consists of a factor that loads on all 255 items; and 3) A correlated factor model, which consists of only two factors, each loading separately on either internalizing or externalizing symptom items. All confirmatory factor analyses were performed in Mplus version 7 (Muthén \& Muthén, 2007) using the weighted least squares means and variance adjusted (WLSMV) 259 algorithm, which is appropriate for ordinal data, and type=complex with the 'cluster' 
medRxiv preprint doi: https://doi.org/10.1101/2021.03.20.21253838; this version posted August 16, 2021. The copyright holder for this preprint (which was not certified by peer review) is the author/funder, who has granted medRxiv a license to display the preprint in It is made available under a CC-BY-NC-ND 4.0 International license .

option, to account for the structure of the data (i.e., twins nested within families). This was done for each age (i.e., 3, 5, 6.5, and 8-9) separately.

We assessed how well each of the three models (one factor, correlated factors, and bifactor model) fit the data using the comparative fit index (CFI), the TuckerLewis index (TLI), and the root-mean square error of approximation (RMSEA). CFI and TLI closer to 1 and RMSEA closer to 0 indicate good fit (Hu \& Bentler, 1999).

\section{Externally validating the psychopathology factors}

To test the external validity of the psychopathology factors, we examined the association between the three factor scores and previously identified correlates of psychological functioning: sex, personality traits and cognitive ability. All analyses were done in $\mathrm{R}$ version 4.0.3 (R Core Team, 2020). The package 'geepack' (Halekoh, Højsgaard, \& Yan, 2006) was used to conduct linear regression analyses with generalized estimating equations (GEE) with an "exchangeable" correlation structure, due to the cluster structure of the data (i.e., families). The factors were entered as independent variables in separate analyses, and either personality traits (age 11) or cognitive ability (age 6.5) were entered as the dependent variables. In the analyses of sex, sex was entered as the independent variable. All models were tested separately.

\section{Longitudinal twin analysis/Cholesky decomposition model}

To test stability and change of the genetic and environmental influences on the psychopathology factors from age 3 to age 8-9 a longitudinal twin analysis/Cholesky decomposition model was conducted. Analyses were done in $\mathrm{R}$ version 4.0.3 (R Core Team, 2020) with the "openMx" (Neale et al., 2016) and "umx" (Bates, Neale, \& Maes, 2016) packages and in the model-fitting program Mx version 1.70a (Neale, 
medRxiv preprint doi: https://doi.org/10.1101/2021.03.20.21253838; this version posted August 16, 2021. The copyright holder for this preprint (which was not certified by peer review) is the author/funder, who has granted medRxiv a license to display the preprint in It is made available under a CC-BY-NC-ND 4.0 International license .

Boker, Xie, \& Maes, 2003). Twin studies take advantage of the genetic difference between MZ twins, who share $100 \%$ of their genes, and DZ twins, who share on average $50 \%$ of their genes. The twin design assumes that if $\mathrm{MZ}$ twins are more similar than DZ twins then the individual differences in the examined phenotype are genetically influenced. These genetic influences can be represented by additive (A) and non-additive/dominant (D) genetic effects. Similarity beyond these genetic influences is attributed to the environment the twins share (shared or common environmental effects, C), and any differences between the twins are ascribed to the non-shared environment, which also includes measurement error (E). In a model that 294 only includes reared-together twins, it is not possible to estimate D and C 295 simultaneously. Therefore, when the presence of the D component is suggested (i.e., 296 the $\mathrm{MZ}$ correlation is more than twice as large than the $\mathrm{DZ}$ correlation), an ADE model needs to be estimated instead of an ACE model. When DZ correlations are negative, a model that also includes a contrast effect has been suggested (Saudino, Cherny, \& Plomin, 2000), as will be explained below.

In a longitudinal genetic model, a heritability component named A1 is created that estimates the variance explained by genetic influences on the first $p$-factor (age 3). The contribution of $\mathrm{A} 1$ to the $p$-factors at later ages (i.e., 5, 6.5, and 8-9) is also 304 development. Similarly, a heritability component named A2 is created that assesses 305 the variance explained by genetic influences that are not accounted for by A1 and that 306 affect the second (i.e., age 5 -factor) and successive waves (i.e., ages 6.5 and 8-9). 307 This is done for each age and for each of the model's components (e.g., A, C, and E). 308 Notably, when certain components are estimated to be very low, constrained models, 309 in which these components are equated to zero, are fitted (e.g., an AE or a DE model). 
medRxiv preprint doi: https://doi.org/10.1101/2021.03.20.21253838; this version posted August 16, 2021. The copyright holder for this preprint (which was not certified by peer review) is the author/funder, who has granted medRxiv a license to display the preprint in It is made available under a CC-BY-NC-ND 4.0 International license .

310 A best fitting model can be chosen based on the lowest Akaike information criterion 311 (AIC).

The psychopathology factors as predictors and Predicting the psychopathology

314 factors

315 Associations between the psychopathology factors and related measures were also 316 performed in $\mathrm{R}$ in GEE models as explained above in the Validating the p-factor 317 section (when developmental problems at age 8-9 were tested as the dependent 318 variable, a logistic regression with GEE was performed). Here, sex (coded as $3191=$ males, $2=$ female), age, and SES at age 3 were used as covariates.

\section{Results}

Descriptive statistics are available in Supporting Table 2.

325 At all four ages, the structural model that fit the data best and showed adequate to 326 good fit was the bifactor model; this was evidenced by the highest CFI and TLI scores 327 and the lowest RMSEA value among the three models (Supporting Table 3). Factor 328 scores from the bifactor model at each age were extracted and used in following 329 analyses. The items and their standardized loadings on each factor are presented in 330 Supporting Table 3. The strength of the loading on each item was relatively consistent 331 between early and middle childhood, so that items with higher loadings on the $p$ 332 factor at age 3 had higher loadings in all 4 waves (the correlations between the factor 333 loadings at each age ranged between .97 and .98). 
medRxiv preprint doi: https://doi.org/10.1101/2021.03.20.21253838; this version posted August 16, 2021. The copyright holder for this preprint (which was not certified by peer review) is the author/funder, who has granted medRxiv a license to display the preprint in It is made available under a CC-BY-NC-ND 4.0 International license .

We examined longitudinal invariance of the $p$-factor by constraining the $p$ -

335 factor loadings to equal across ages and comparing this nested model to the 336 unconstrained model. As in the original models, all means were fixed at 0 and the 337 variances were fixed at 1 , for model identification and standardization of the factors. 338 To compare the models, we employed the DIFFTEST option in Mplus, which enables 339 a chi-square difference test analysis when the WLSMV estimators is used. The 340 difference test was significant ( $\chi^{2}$ diff $\left.(60)=138.66, \mathrm{p}<.0001\right)$, however, the RMSEA 341 (.018), CFI (.914), and TLI (.909) in the unconstrained model were similar to the 342 RMSEA (.017), CFI (.919), and TLI (.915) of the nested model. Therefore, and taking 343 into consideration that chi-square tests are considered overly conservative in large 344 sample sizes, it can be concluded that the $p$-factor is relatively stable during 345 childhood. This is also supported by the correlations between the $p$, externalizing, and 346 internalizing factor scores across ages (shown in Figure 1A. For purposes of the 347 figure, we limited the sample to one random twin in each family to avoid dependency 348 and allow a simple presentation). The correlations between the $p$-factor at different 349 ages were consistently moderate to high $(\mathrm{r}=.45-.68)$. Correlations between the 350 internalizing factors $(\mathrm{r}=.37-.58)$ and between the externalizing factors $(\mathrm{r}=.34-.67)$ 351 were of similar magnitude.

\section{Externally validating the psychopathology factors}

354 Patterns of association were examined across childhood between the psychopathology 355 factors ( $p$, externalizing, and internalizing), the big five personality traits (self356 reports), cognitive ability (lab assessment), and sex. The psychopathology factors at 357 each age were analyzed separately. Results are presented in Table 1 and Supporting 358 Table 4. As expected, children with higher $p$-factor scores, tended to rate themselves 
medRxiv preprint doi: https://doi.org/10.1101/2021.03.20.21253838; this version posted August 16, 2021. The copyright holder for this preprint (which was not certified by peer review) is the author/funder, who has granted medRxiv a license to display the preprint in It is made available under a CC-BY-NC-ND 4.0 International license .

359 as less agreeable, less conscientious, and more neurotic. Children with higher 360 internalizing factor scores rated themselves as less extraverted and more neurotic, 361 while children with higher externalizing factor scores rated themselves as more 362 extraverted and less conscientious.

Across ages 3 to 8-9, boys had higher $p$-factor scores than girls. Boys were also characterized by higher externalizing factor scores than girls, while girls tended to score higher on the internalizing factor, although this latter association was weak and inconsistent across ages. Cognitive ability, as assessed at age 6.5, showed the strongest negative association with the externalizing factor $\left(\mathrm{R}^{2}\right.$ between .007 and .058 ), and only weak and inconsistent associations with $p$ and the internalizing factor $\left(\mathrm{R}^{2}\right.$ between 0 and .005$)$.

\section{Longitudinal twin analysis/Cholesky decomposition model}

Twin correlations for the psychopathology factors from early to middle childhood are

373 presented in Figure 1B. MZ twin correlations were consistently higher than DZ twin 374 correlations. Notably, in the case of the specific/residualized externalizing factor, DZ correlations were negative and weak, whereas MZ correlations were consistently moderate and ranged between .43 to .49 . Sensitivity analyses showed that regressing

377 the psychopathology factors on sex or excluding the DZ-opposite sex twins did not 378 lead to meaningful changes in the correlations between MZ and DZ twins (Supporting 379 Table 5). For the $p$-factor the AE model fit the data best (Supporting Table 6) and is 381 presented in Figure 2A (estimates with 95\% confidence intervals are presented in 382 Supporting Table 7A; because the difference in fit was small, an ADE model is also 383 presented in Supporting Table 7B). The analysis indicated that the genetic influences 
medRxiv preprint doi: https://doi.org/10.1101/2021.03.20.21253838; this version posted August 16, 2021. The copyright holder for this preprint (which was not certified by peer review) is the author/funder, who has granted medRxiv a license to display the preprint in It is made available under a CC-BY-NC-ND 4.0 International license

384

385

386

on the $p$-factor are substantial and relatively stable in size (total heritability at each age ranged from .64 to .73), and that although new genetic influences arise at each age, a major proportion of the genetic influence is already present at age 3, and persists throughout childhood.

As mentioned above, for the externalizing factor, DZ correlations were negative. Negative DZ twin correlations have been observed in previous studies (e.g., Goodman \& Stevenson, 1989; Plomin et al., 1993), and specifically for hyperactivity (Thapar, Holmes, Poulton, \& Harrington, 1999). Such correlations are thought to arise due to a contrast effect, which, in the case of negative DZ correlations, likely represents a bias in parent ratings (Saudino et al., 2000). In genetically influenced traits, DZ twins are expected to be more different than MZ twins. A contrast effect describes a situation in which parents exaggerate the existing difference between DZ twins. In addition to negative DZ correlations, a contrast effect is suggested when the DZs variance is greater than the MZs variance (Saudino et al., 2000). In our sample, the externalizing factor variance was consistently greater in DZs compared to MZs, although the differences were only significant in ages 3 and 5 (Supporting Table 8).

Based on the above, we opted to test a model for the externalizing factor that also accounts for a contrast effect (i.e., a path at each age from each twin's phenotype to the phenotype of their co-twin. This path indicates that each twin's phenotype is also a function of their co-twin's phenotype) as shown in Saudino et al., (2000). Indeed, an ACE model with a contrast effect showed the best fit (Supporting Table 6). This model (without the contrast effect for simplicity of presentation) is shown in Figure 2B (estimates and contrast effects with $95 \%$ confidence intervals are presented in Supporting Table 9; the second best fitting model, the ADE model, is presented in Supporting Table 9B). The contrast effect at each age ranged between -.26 and -.32, 
medRxiv preprint doi: https://doi.org/10.1101/2021.03.20.21253838; this version posted August 16, 2021. The copyright holder for this preprint (which was not certified by peer review) is the author/funder, who has granted medRxiv a license to display the preprint in It is made available under a CC-BY-NC-ND 4.0 International license .

409 suggesting the presence of parental bias. After accounting for this bias, the main 410 portion of the variance across childhood was accounted for by genetic influences. The 411 remaining variance tended to divide relatively evenly between the shared and non412 shared environment. The genetic influences at age 3 continued to contribute to the 413 variance across childhood. Notably, the shared environment confidence intervals were 414 very large, suggesting the need to investigate these effects in a sample with greater 415 statistical power. For the internalizing factor, the DE model fit the data best (Supporting Table 6).

417 However, a model with a dominant genetic effect (i.e., interaction effects), without an 418 additive effect (i.e., main effect), is considered unlikely (Evans, 2020), and we 419 therefore show the second best fitting model in Figure 2C, which is the ADE model 420 (estimates with 95\% confidence intervals are presented in Supporting Table 10A, and 421 the DE model is presented in Supporting Table 10B). The ADE model for the 422 internalizing factor suggested that about half (.41-.60) of the individual differences in 423 internalizing symptoms from early to middle childhood are affected by genetic 424 influences (whether additive or dominant). Most of these genetic effects were already 425 present at age 3 or 5 , suggesting that a large proportion of the genetic influences on 426 internalizing symptoms is stable from early to middle childhood. The rest of the 427 variance was accounted for by non-shared environmental effects and measurement 428 error. The psychopathology factors as predictors

431 The $p$-factor was the most consistent and reliable of the three psychopathology factors 432 in predicting developmental problems at age 8-9 (odds ratios ranging between 1.42 433 and 1.84; see Figure 3 and additional statistics in Supporting Table 11A). 
medRxiv preprint doi: https://doi.org/10.1101/2021.03.20.21253838; this version posted August 16, 2021. The copyright holder for this preprint (which was not certified by peer review) is the author/funder, who has granted medRxiv a license to display the preprint in It is made available under a CC-BY-NC-ND 4.0 International license

434 Interestingly, the $p$-factor retained its value as a predictor, as early as age 3, even 435 when developmental problems from the same age as the $p$-factor were included in the 436 model (odds ratios ranging between 1.36 and 1.60; Figure 3 and Supporting Table 437 11B).

The $p$-factor was also the best predictor of self-esteem at age $11\left(\mathrm{R}^{2}\right.$ ranging 439 from .015 to .04), indicating that, on average, children with higher $p$-factor scores 440 reported lower self-esteem at age 11. Interestingly, the externalizing factor was the 441 best predictor of life satisfaction at age $13\left(\mathrm{R}^{2}\right.$ ranging from .007 to .014$)$; children 442 with higher externalizing symptoms tended to report poorer life satisfaction (Figure 3 443 and Supporting Table 11C).

\section{Predicting the psychopathology factors}

446 Exploratory analyses, examining possible early-life predictors of the psychopathology 447 factors, are presented in Table 2 and Supporting Table 12, which includes additional 448 information such as p-values corrected for multiple comparisons. Most predictors explained about $1 \%$ or less of the variance in the psychopathology factors. On average across waves, the summary score of neonatal problems, which consisted of neonatal hepatitis, neonatal diabetes, and having been in an incubator, explained the most $p$ factor variance at each age $\left(\mathrm{R}^{2}\right.$ from .004 to .013$)$, such that greater neonatal problems 453 were associated with higher $p$-factor scores across childhood. .005 to .017); children raised in families with higher SES tended to have fewer internalizing symptoms. For the externalizing factor, developmental problems at age 3 458 explained the most variance on average across waves $\left(\mathrm{R}^{2}\right.$ ranging from .006 to .01$)$; 
medRxiv preprint doi: https://doi.org/10.1101/2021.03.20.21253838; this version posted August 16, 2021. The copyright holder for this preprint (which was not certified by peer review) is the author/funder, who has granted medRxiv a license to display the preprint in It is made available under a CC-BY-NC-ND 4.0 International license

459 children with more developmental problems at age 3 tended to have more 460 externalizing symptoms across childhood.

461

\section{Discussion}

In the current study, we investigated the $p$-factor and the more specific/residualized internalizing and externalizing factors from early to middle childhood. In general, we found that 1) the $p$-factor is present in children as young as 3 years old; 2) there is little to no effect of the shared-environment for $p$ and the specific/residualized internalizing factor, and all factors show strong and relatively stable genetic influences; 3) early life measure, such as childhood SES and neonatal and pregnancy risk, while at times significantly associated with the $p$-factor, do not explain more than $1 \%$ of the variance in any of the three psychopathology factors; and 4) the $p$-factor in early childhood can help to predict developmental problems and self-esteem in ages $8-9$ and 11 , respectively.

Our analyses indicated that a bifactor model which includes a general psychopathology factor, i.e., the $p$-factor, and two specific/residualized factors (internalizing and externalizing), fit the data best across all four waves from early to middle childhood. This supports and replicates previous findings of a transdiagnostic factor in childhood (e.g., McElroy, Belsky, Carragher, Fearon, \& Patalay, 2018; Morales et al., 2021). However, the use of fit indices for determining the model that best represents the structure of psychopathology has been criticized, as simulations have shown that the bifactor model is found as the best fitting model even when simulated data is created based on a correlated factors model (Greene et al., 2019). We were therefore interested in externally validating the $p$-factor, by examining its association with known correlates. 
medRxiv preprint doi: https://doi.org/10.1101/2021.03.20.21253838; this version posted August 16, 2021. The copyright holder for this preprint (which was not certified by peer review) is the author/funder, who has granted medRxiv a license to display the preprint in It is made available under a CC-BY-NC-ND 4.0 International license .

Indeed, as previous studies on different samples have indicated (Avinun et al.,

485

486

487

2020; Caspi et al., 2014; Etkin et al., 2020), the $p$-factor is negatively associated with agreeableness and conscientiousness, and positively associated with neuroticism. It is noteworthy that in our study the $p$-factor was estimated based on mother reports, while personality traits were assessed by self-reports of the children, thus ruling out shared method (source) variance as accounting for this association. The externalizing factor (net of $p$ ) was negatively associated with conscientiousness and positively associated with extraversion. In contrast, the internalizing factor (net of $p$ ) was positively associated with neuroticism and negatively associated with extraversion. This association between the three psychopathology factors and profiles of Big Five traits has now been demonstrated across cohorts varying in age and culture, and further supports the notion of overlapping taxonomies between the basic structure of personality and psychopathology (Brandes, Herzhoff, Smack, \& Tackett, 2019).

We found that the externalizing factor (net of $p$ ) was most strongly associated with cognitive ability, a finding that is inconsistent with previous studies in which the $p$-factor was more strongly associated with measures of executive functioning (Caspi \& Moffitt, 2018; Martel et al., 2017). It is possible that the use of different measurements or the reliance on symptom-level (our study) rather than diagnosislevel measures for the factor analysis (symptom counts or diagnostic probabilistic bands; Caspi \& Moffitt, 2018; Martel et al., 2017) account for this inconsistency. Alternatively, if psychopathology is causal to cognitive impairment, it may be that disruptions to cognitive ability have yet to emerge in our young sample. Lastly, the items with the highest loadings on the externalizing factor related to inattention (e.g., easily distracted and cannot concentrate or finish tasks) which likely affected the children's performance during the cognitive ability tasks. 
medRxiv preprint doi: https://doi.org/10.1101/2021.03.20.21253838; this version posted August 16, 2021. The copyright holder for this preprint (which was not certified by peer review) is the author/funder, who has granted medRxiv a license to display the preprint in It is made available under a CC-BY-NC-ND 4.0 International license .

509

510

511

512

513

514

515

516

The predictive utility of the $p$-factor was demonstrated by its positive association with developmental problems at age 8-9 and negative association with self-esteem, as measured in age 11 and self-reported by the children. While the specific developmental pathways leading to the latter association remain to be elucidated, one possibility may relate to previous findings showing that neuroticism, depression, and self-esteem are affected by shared genetic influences (Neiss, Stevenson, Legrand, Iacono, \& Sedikides, 2009), suggesting that they have a shared etiology. Alternatively, psychopathology may increase the risk of exposure to stressful experiences, such as being bullied (Arseneault, Bowes, \& Shakoor, 2010), leading to poorer self-esteem. Future research aimed at identifying these pathways has implications for how to most effectively target interventions.

Our finding of model invariance, as suggested by fit statistics, together with moderate to high correlations between the $p$-factor across waves, and relatively consistent factor loadings, which showed little change during development from early to middle childhood, indicated that $p$ is reliable and stable across childhood. Additional support for the reliability of the $p$-factor was obtained from our longitudinal genetic analysis, which indicated that the $p$-factor was substantially heritable and that the genetic effects on the $p$-factor at age 3 meaningfully contribute to the genetic influences on the $p$-factor in all ages. The only previous longitudinal genetic study of the $p$-factor included twins from age 7 to 16 and has also found that the $p$-factor is highly heritable and that genetic factors contribute to stability (Allegrini et al., 2020).

Our longitudinal genetic analyses showed that genetic effects accounted for a large portion of the variance in the internalizing (.41-.60) and externalizing (.51-.72) factors. For the internalizing factor, both additive and dominant genetic influences 
medRxiv preprint doi: https://doi.org/10.1101/2021.03.20.21253838; this version posted August 16, 2021. The copyright holder for this preprint (which was not certified by peer review) is the author/funder, who has granted medRxiv a license to display the preprint in It is made available under a CC-BY-NC-ND 4.0 International license .

534 (i.e., both main effects and interactions between genetic variants) were indicated, and 535 there was no evidence for shared environment influences. The remaining variance was 536 accounted for by the non-shared environment. For the externalizing factor a contrast 537 effect was found, suggesting that parents tend to exaggerate the differences in 538 externalizing symptoms between DZ twins. Thus, future studies should use 539 observational methods or interviews to study the longitudinal genetic and 540 environmental effects on the specific/residualized factors. Variance in the 541 externalizing factor (net of $p$ ) not accounted for by genetic influences was evenly 542 divided between the shared and non-shared environment. Importantly, the broad 543 confidence intervals of the models for both specific/residualized factors, suggested 544 that a larger sample with more statistical power may be needed.

Although the $p$-factor appears to represent a real shared general risk for 546 psychopathology, its origins remain unclear. Here, we examined whether measures 547 that can be assessed in early life, such as early childhood SES and pregnancy or 548 neonatal complications, can predict the $p$-factor in childhood. This was guided by 549 previous research suggesting that early childhood SES and fetal and early life 550 programming may be linked to mental health (Lewis, Galbally, Gannon, \& 551 Symeonides, 2014; O’Donnell \& Meaney, 2017; Peverill et al., 2020). All measures 552 showed only weak associations, if at all, with the $p$-factor, explaining $1 \%$, and usually 553 less, of the factor variance. This was also true for the specific/residualized 554 externalizing and internalizing factors. Similarly, developmental problems at age 3 555 did not explain more than $1 \%$ of the variance in the psychopathology factors. Taken 556 together, these suggest that a cumulative risk factor score composed of many fetal and 557 early life stressors may be a better approach for the prediction of the latent factors of 558 psychopathology (Meehan et al., 2020). 
medRxiv preprint doi: https://doi.org/10.1101/2021.03.20.21253838; this version posted August 16, 2021. The copyright holder for this preprint (which was not certified by peer review) is the author/funder, who has granted medRxiv a license to display the preprint in It is made available under a CC-BY-NC-ND 4.0 International license .

Strengths and Limitations

561 To our knowledge, the current study is the first to provide an in-depth developmental 562 and longitudinal genetic investigation of the specific/residualized externalizing and 563 internalizing factors from the bifactor model and the first to examine the links 564 between the general and specific/residualized factors of psychopathology and 565 pregnancy, obstetric, and neonatal measures. However, this study also has several 566 limitations. First, the assessment of psychopathology was restricted to maternal 567 reports and relied on a relatively limited number of items. While this is not 568 exceptional (e.g., McElroy et al., 2018; Patalay et al., 2015), further research is 569 needed to understand how these and the inclusion of only identical items across ages, 570 affected the findings. Second, our sample consisted only of twins and therefore the 571 generalizability of the associations between the psychopathology factors and other 572 measures need to be replicated. Notably however, in the context of the associations 573 with the pregnancy, obstetric, and neonatal measures, the reliance on twins was 574 advantageous, as twin pregnancies are associated with higher complications compared 575 to singletons (Obiechina, Okolie, Eleje, Okechukwu, \& Anemeje, 2011), allowing for 576 greater variance. Third, our study was restricted to the developmental period of early 577 to mid-childhood; research encompassing longer developmental periods is needed.

579 Conclusions

580 Our study supports accumulating research indicating a general factor of 581 psychopathology, which represents transdiagnostic risk across mental disorders (Caspi $582 \&$ Moffitt, 2018), and shows that this general factor is highly heritable, discernible in 583 early childhood, and stable from early to mid-childhood. Results also suggest that the 
medRxiv preprint doi: https://doi.org/10.1101/2021.03.20.21253838; this version posted August 16, 2021. The copyright holder for this preprint (which was not certified by peer review) is the author/funder, who has granted medRxiv a license to display the preprint in It is made available under a CC-BY-NC-ND 4.0 International license .

$584 p$-factor is not meaningfully predicted by pregnancy, obstetric, and neonatal events.

585 Lastly, to our knowledge, this is the first in-depth genetically informed investigation

586 of the specific/residualized factors of psychopathology in childhood. Findings

587 indicated moderate to large genetic influences on both specific/residualized factors

588 with a meaningful portion of these influences already present at age 3.

589

590

591

\section{Acknowledgements}

592 We thank the participating families for their cooperation and all the lab members of 593 the Social Development lab throughout the years for data collection and coding. We 594 would also like to thank Prof. Kimberly Saudino for her help with the contrast effect 595 analyses. The Longitudinal Israeli Study of Twins (LIST) was founded by grant No. 596 31/06 from the Israel Science Foundation. The work was further supported by grant 597 No. 1670/13 from the Israel Science Foundation, starting grant No. 240994 from the 598 European Research Council, and by a grant from The Science of Generosity Initiative, 599 funded by the John Templeton Foundation to Ariel Knafo-Noam. RA is supported by 600 a Lady Davis fellowship. The authors declare they have no conflicts of interest.

601

602

\section{Correspondence}

604 Correspondence concerning this article should be addressed to Reut Avinun, $\mathrm{PhD}$, 605 Department of Psychology, The Hebrew University of Jerusalem, Mount Scopus, 606 Jerusalem, 91905 Israel. E-mail: reut.avinun@mail.huji.ac.il 
medRxiv preprint doi: https://doi.org/10.1101/2021.03.20.21253838; this version posted August 16, 2021. The copyright holder for this preprint (which was not certified by peer review) is the author/funder, who has granted medRxiv a license to display the preprint in It is made available under a CC-BY-NC-ND 4.0 International license .

607

608

609

610

611

612

613

614

615

616

617

618

619

620

621

622

623

624

625

626

627

628

629

630

631

632

633

634

635

636

637

638

639

\section{References}

Allegrini, A. G., Cheesman, R., Rimfeld, K., Selzam, S., Pingault, J. B., Eley, T. C., \& Plomin, R. (2020). The p factor: genetic analyses support a general dimension of psychopathology in childhood and adolescence. Journal of Child Psychology and Psychiatry, 61(1), 30-39.

Arseneault, L., Bowes, L., \& Shakoor, S. (2010). Bullying victimization in youths and mental health problems:'much ado about nothing'? Psychological Medicine, 40(5), 717.

Avinun, R., \& Knafo-Noam, A. (2017). Parental brain-derived neurotrophic factor genotype, child prosociality, and their interaction as predictors of parents' warmth. Brain and Behavior, 7(5).

Avinun, R., \& Knafo, A. (2013). The Longitudinal Israeli Study of Twins (LIST) An Integrative View of Social Development. Twin Research and Human Genetics, 16(1), 197-201. doi: 10.1017/thg.2012.73

Avinun, R., Romer, A. L., \& Israel, S. (2020). Vitamin D polygenic score is associated with neuroticism and the general psychopathology factor. Progress in Neuro-Psychopharmacology and Biological Psychiatry, 109912.

Bates, T., Neale, M., \& Maes, H. (2016). umx: A library for Structural Equation and Twin Modelling in R. Journal of statistical software.

Blanco, C., Wall, M. M., Hoertel, N., Krueger, R. F., Liu, S.-M., Grant, B. F., \& Olfson, M. (2019). Psychiatric disorders and risk for multiple adverse outcomes: a national prospective study. Molecular Psychiatry, 1-10.

Brandes, C. M., Herzhoff, K., Smack, A. J., \& Tackett, J. L. (2019). The p factor and the $\mathrm{n}$ factor: Associations between the general factors of psychopathology and neuroticism in children. Clinical Psychological Science, 7(6), 1266-1284.

Buss, A. H., \& Plomin, R. (1984). Temperament: early developing personality traits. Hillsdale, NJ: Lawrence Erlbaum Associates, Inc.

Caspi, A., Houts, R. M., Belsky, D. W., Goldman-Mellor, S. J., Harrington, H., Israel, S., . . Moffitt, T. E. (2014). The p factor: one general psychopathology factor in the structure of psychiatric disorders? Clinical Psychological Science, 2(2), 119-137.

Caspi, A., \& Moffitt, T. E. (2018). All for one and one for all: Mental disorders in one dimension. American Journal of Psychiatry, 175(9), 831-844. 
medRxiv preprint doi: https://doi.org/10.1101/2021.03.20.21253838; this version posted August 16, 2021. The copyright holder for this preprint (which was not certified by peer review) is the author/funder, who has granted medRxiv a license to display the preprint in It is made available under a CC-BY-NC-ND 4.0 International license .

640

641

642

643

644

645

646

647

648

649

650

651

652

653

654

655

656

657

658

659

660

661

662

663

664

665

666

667

668

669

670

671

672

673

Chiorean, A., Savoy, C., Beattie, K., el Helou, S., Silmi, M., \& Van Lieshout, R. J. (2020). Childhood and adolescent mental health of NICU graduates: an observational study. Archives of Disease in Childhood, 105, 684-689. doi: 10.1136/archdischild-2019-318284

De Mola, C. L., De França, G. V. A., de Avila Quevedo, L., \& Horta, B. L. (2014). Low birth weight, preterm birth and small for gestational age association with adult depression: systematic review and meta-analysis. The British Journal of Psychiatry, 205(5), 340-347.

Ehrenstein, V., Pedersen, L., Grijota, M., Nielsen, G. L., Rothman, K. J., \& Sørensen, H. T. (2009). Association of Apgar score at five minutes with long-term neurologic disability and cognitive function in a prevalence study of Danish conscripts. BMC pregnancy and childbirth, 9(1), 1-7.

Etkin, P., Mezquita, L., López-Fernández, F. J., Ortet, G., \& Ibáñez, M. I. (2020). Five Factor model of personality and structure of psychopathological symptoms in adolescents. Personality and Individual Differences, 163, 110063.

Evans, D. M. (2020). The Boulder Workshop Question Box. Behavior Genetics, 1-10.

Githens, P. B., Glass, C. A., Sloan, F. A., \& Entman, S. S. (1993). Maternal recall and medical records: an examination of events during pregnancy, childbirth, and early infancy. Birth, 20(3), 136-141.

Goldsmith, H. (1991). A zygosity questionnaire for young twins: A research note. Behavior Genetics, 21(3), 257-269.

Gomez, R., Stavropoulos, V., Vance, A., \& Griffiths, M. D. (2019). Re-evaluation of the latent structure of common childhood disorders: Is there a general psychopathology factor (p-factor)? International Journal of Mental Health and Addiction, 17(2), 258-278.

Goodman, R. (1997). The Strengths and Difficulties Questionnaire: a research note. Journal of child psychology and psychiatry, and allied disciplines, 38(5), 581.

Goodman, R., \& Stevenson, J. (1989). A twin study of hyperactivity-II. The aetiological role of genes, family relationships and perinatal adversity. Journal of Child Psychology and Psychiatry, 30(5), 691-709.

Greene, A. L., Eaton, N. R., Li, K., Forbes, M. K., Krueger, R. F., Markon, K. E., . . . Docherty, A. R. (2019). Are fit indices used to test psychopathology structure biased? A simulation study. Journal of Abnormal Psychology, 128(7), 740. 
medRxiv preprint doi: https://doi.org/10.1101/2021.03.20.21253838; this version posted August 16, 2021. The copyright holder for this preprint (which was not certified by peer review) is the author/funder, who has granted medRxiv a license to display the preprint in It is made available under a CC-BY-NC-ND 4.0 International license .

674

675

676

677

678

679

680

681

682

683

684

685

686

687

688

689

690

691

692

693

694

695

696

697

698

699

700

701

702

703

704

705

706

Halekoh, U., Højsgaard, S., \& Yan, J. (2006). The R package geepack for generalized estimating equations. Journal of statistical software, 15(2), 1-11.

Hamlyn, J., Duhig, M., McGrath, J., \& Scott, J. (2013). Modifiable risk factors for schizophrenia and autism-shared risk factors impacting on brain development. Neurobiology of Disease, 53, 3-9.

Hankin, B. L., Davis, E. P., Snyder, H., Young, J. F., Glynn, L. M., \& Sandman, C. A. (2017). Temperament factors and dimensional, latent bifactor models of child psychopathology: Transdiagnostic and specific associations in two youth samples. Psychiatry Research, 252, 139-146.

Hu, L. t., \& Bentler, P. M. (1999). Cutoff criteria for fit indexes in covariance structure analysis: Conventional criteria versus new alternatives. Structural equation modeling: a multidisciplinary journal, 6(1), 1-55.

Huebner, E. S. (1991). Initial development of the student's life satisfaction scale. School Psychology International, 12(3), 231-240.

Hughes, C., \& Ensor, R. (2011). Individual differences in growth in executive function across the transition to school predict externalizing and internalizing behaviors and self-perceived academic success at 6 years of age. Journal of Experimental Child Psychology, 108(3), 663-676.

Hyland, P., Murphy, J., Shevlin, M., Carey, S., Vallières, F., Murphy, D., \& Elklit, A. (2018). Correlates of a general psychopathology factor in a clinical sample of childhood sexual abuse survivors. Journal of Affective Disorders, 232, 109115.

John, O. P., Donahue, E., \& Kentle, R. (1991). The big five inventory: Versions $4 a$ and 54 (Technical report). Berkeley: University of California, Institute of Personality and Social Research.

Laceulle, O. M., Chung, J. M., Vollebergh, W. A., \& Ormel, J. (2020). The wide-ranging life outcome correlates of a general psychopathology factor in adolescent psychopathology. Personality and mental health, 14(1), 9-29.

Lahey, B. B., Applegate, B., Hakes, J. K., Zald, D. H., Hariri, A. R., \& Rathouz, P. J. (2012). Is there a general factor of prevalent psychopathology during adulthood? Journal of Abnormal Psychology, 121(4), 971.

Lahey, B. B., Rathouz, P. J., Keenan, K., Stepp, S. D., Loeber, R., \& Hipwell, A. E. (2015). Criterion validity of the general factor of psychopathology in a 
medRxiv preprint doi: https://doi.org/10.1101/2021.03.20.21253838; this version posted August 16, 2021. The copyright holder for this preprint (which was not certified by peer review) is the author/funder, who has granted medRxiv a license to display the preprint in It is made available under a CC-BY-NC-ND 4.0 International license.

707

708

709

710

711

712

713

714

715

716

717

718

719

720

721

722

723

724

725

726

727

728

729

730

731

732

733

734

735

736

737

738

739

prospective study of girls. Journal of Child Psychology and Psychiatry, 56(4), 415-422.

Lerner, M. J., \& Miller, D. T. (1978). Just world research and the attribution process: looking back and ahead. Psychological bulletin, 85(5), 1030.

Lewis, A. J., Galbally, M., Gannon, T., \& Symeonides, C. (2014). Early life programming as a target for prevention of child and adolescent mental disorders. BMC Medicine, 12(1), 1-15.

Liu, J., Raine, A., Wuerker, A., Venables, P. H., \& Mednick, S. (2009). The association of birth complications and externalizing behavior in early adolescents: direct and mediating effects. Journal of Research on Adolescence, 19(1), 93-111.

Martel, M. M., Pan, P. M., Hoffmann, M. S., Gadelha, A., do Rosário, M. C., Mari, J. J., . . Bressan, R. A. (2017). A general psychopathology factor (P factor) in children: structural model analysis and external validation through familial risk and child global executive function. Journal of Abnormal Psychology, 126(1), 137.

McElroy, E., Belsky, J., Carragher, N., Fearon, P., \& Patalay, P. (2018). Developmental stability of general and specific factors of psychopathology from early childhood to adolescence: dynamic mutualism or p-differentiation? Journal of Child Psychology and Psychiatry, 59(6), 667-675.

Meehan, A. J., Latham, R. M., Arseneault, L., Stahl, D., Fisher, H. L., \& Danese, A. (2020). Developing an individualized risk calculator for psychopathology among young people victimized during childhood: A populationrepresentative cohort study. Journal of Affective Disorders, 262, 90-98.

Merikangas, K. R., He, J.-p., Burstein, M., Swanson, S. A., Avenevoli, S., Cui, L., . . Swendsen, J. (2010). Lifetime prevalence of mental disorders in US adolescents: results from the National Comorbidity Survey ReplicationAdolescent Supplement (NCS-A). Journal of the American Academy of Child and Adolescent Psychiatry, 49(10), 980-989.

Morales, S., Tang, A., Bowers, M. E., Miller, N. V., Buzzell, G. A., Smith, E., . . . Fox, N. A. (2021). Infant temperament prospectively predicts general psychopathology in childhood. Development and Psychopathology, 1-10. doi: 10.1017/s0954579420001996 
medRxiv preprint doi: https://doi.org/10.1101/2021.03.20.21253838; this version posted August 16, 2021. The copyright holder for this preprint (which was not certified by peer review) is the author/funder, who has granted medRxiv a license to display the preprint in It is made available under a CC-BY-NC-ND 4.0 International license .

740

741

742

743

744

745

746

747

748

749

750

751

752

753

754

755

756

757

758

759

760

761

762

763

764

765

766

767

768

769

770

771

Murray, A. L., Eisner, M., \& Ribeaud, D. (2016). The development of the general factor of psychopathology ' $\mathrm{p}$ factor'through childhood and adolescence. Journal of Abnormal Child Psychology, 44(8), 1573-1586.

Muthén, L. K., \& Muthén, B. O. (2007). Mplus User's Guide. Los Angeles, CA: Muthén \& Muthén.

Neale, M., Boker, S., Xie, G., \& Maes, H. (2003). Mx: Statistical Modeling. Richmond, VA: Department of Psychiatry, Virginia Institute for Psychiatric and Behavior Genetics, Virginia Commonwealth University.

Neale, M. C., Hunter, M. D., Pritikin, J. N., Zahery, M., Brick, T. R., Kirkpatrick, R. M., .. . Boker, S. M. (2016). OpenMx 2.0: Extended structural equation and statistical modeling. Psychometrika, 81(2), 535-549.

Neiss, M. B., Stevenson, J., Legrand, L. N., Iacono, W. G., \& Sedikides, C. (2009). Self-esteem, negative emotionality, and depression as a common temperamental core: A study of mid-adolescent twin girls. Journal of Personality, 77(2), 327-346.

Newman, D. L., Moffitt, T. E., Caspi, A., \& Silva, P. A. (1998). Comorbid mental disorders: implications for treatment and sample selection. Journal of Abnormal Psychology, 107(2), 305.

Nosarti, C., Reichenberg, A., Murray, R. M., Cnattingius, S., Lambe, M. P., Yin, L., . . Hultman, C. M. (2012). Preterm birth and psychiatric disorders in young adult life. Archives of General Psychiatry, 69(6), 610-617.

O’Donnell, K. J., \& Meaney, M. J. (2017). Fetal origins of mental health: the developmental origins of health and disease hypothesis. American Journal of Psychiatry, 174(4), 319-328.

Obiechina, N., Okolie, V., Eleje, G., Okechukwu, Z., \& Anemeje, O. (2011). Twin versus singleton pregnancies: the incidence, pregnancy complications, and obstetric outcomes in a Nigerian tertiary hospital. International journal of women's health, 3, 227.

Olino, T. M., Dougherty, L. R., Bufferd, S. J., Carlson, G. A., \& Klein, D. N. (2014). Testing models of psychopathology in preschool-aged children using a structured interview-based assessment. Journal of Abnormal Child Psychology, 42(7), 1201-1211. 
medRxiv preprint doi: https://doi.org/10.1101/2021.03.20.21253838; this version posted August 16, 2021. The copyright holder for this preprint (which was not certified by peer review) is the author/funder, who has granted medRxiv a license to display the preprint in It is made available under a CC-BY-NC-ND 4.0 International license .

772

773

774

775

776

777

778

779

780

781

782

783

784

785

786

787

788

789

790

791

792

793

794

795

796

797

798

799

800

801

802

803

804

805

Patalay, P., Fonagy, P., Deighton, J., Belsky, J., Vostanis, P., \& Wolpert, M. (2015). A general psychopathology factor in early adolescence. The British Journal of Psychiatry, 207(1), 15-22.

Pettersson, E., Lahey, B. B., Larsson, H., \& Lichtenstein, P. (2018). Criterion Validity and Utility of the General Factor of Psychopathology in Childhood: Predictive Associations With Independently Measured Severe Adverse Mental Health Outcomes in Adolescence. Journal of the American Academy of Child and Adolescent Psychiatry, 57(6), 372-383.

Peverill, M., Dirks, M. A., Narvaja, T., Herts, K. L., Comer, J. S., \& McLaughlin, K. A. (2020). Socioeconomic status and child psychopathology in the United States: A meta-analysis of population-based studies. Clinical Psychology Review, 101933.

Plomin, R., Kagan, J., Emde, R. N., Reznick, J. S., Braungart, J. M., Robinson, J., . . . Fulker, D. W. (1993). Genetic change and continuity from fourteen to twenty months: The MacArthur Longitudinal Twin Study. Child Development, 64(5), 1354-1376.

R Core Team. (2020). R: A language and environment for statistical computing. Vienna, Austria: $\mathrm{R}$ foundation for Statistical Computing. Retrieved from http://www.R-project.org/

Riglin, L., Thapar, A. K., Leppert, B., Martin, J., Richards, A., Anney, R., . . Lahey, B. B. (2019). Using genetics to examine a general liability to childhood psychopathology. Behavior Genetics, 1-8.

Romer, A. L., Knodt, A. R., Houts, R., Brigidi, B. D., Moffitt, T. E., Caspi, A., \& Hariri, A. R. (2018). Structural alterations within cerebellar circuitry are associated with general liability for common mental disorders. Molecular Psychiatry, 23(4), 1084.

Rosenberg, M. (1965). Society and the adolescent self-image. Princeton, NJ: Princeton University Press.

Saudino, K. J., Cherny, S. S., \& Plomin, R. (2000). Parent ratings of temperament in twins: explaining the 'too low'DZ correlations. Twin Research and Human Genetics, 3(4), 224-233.

Selzam, S., Coleman, J. R., Caspi, A., Moffitt, T. E., \& Plomin, R. (2018). A polygenic $\mathrm{p}$ factor for major psychiatric disorders. Translational Psychiatry, 8(1), 205. 
medRxiv preprint doi: https://doi.org/10.1101/2021.03.20.21253838; this version posted August 16, 2021. The copyright holder for this preprint (which was not certified by peer review) is the author/funder, who has granted medRxiv a license to display the preprint in It is made available under a CC-BY-NC-ND 4.0 International license .

806 Snyder, H. R., Young, J. F., \& Hankin, B. L. (2017). Strong homotypic continuity in 807 common psychopathology-, internalizing-, and externalizing-specific factors 808 over time in adolescents. Clinical Psychological Science, 5(1), 98-110.

809

Thapar, A., Holmes, J., Poulton, K., \& Harrington, R. (1999). Genetic basis of 810 811 attention deficit and hyperactivity. The British Journal of Psychiatry, 174(2), 105-111.

813

Van Lieshout, R. J., \& Voruganti, L. P. (2008). Diabetes mellitus during pregnancy 814 and increased risk of schizophrenia in offspring: a review of the evidence and 815 putative mechanisms. Journal of psychiatry \& neuroscience: JPN, 33(5), 395.

Vertsberger, D., Abramson, L., \& Knafo-Noam, A. (2019). The Longitudinal Israeli Study of Twins (LIST) Reaches Adolescence: Genetic and Environmental Pathways to Social, Personality and Moral Development. Twin Research and Human Genetics, 22(6), 567-571. 
Table 1. Associations between the three psychopathology factors, personality traits, cognitive ability, and sex from early to middle childhood. Standardized estimates and standard errors from generalized estimating equation models are presented.

\begin{tabular}{|c|c|c|c|c|c|c|c|c|}
\hline & \multicolumn{3}{|c|}{$p$ factor } & \multicolumn{5}{|c|}{ Internalizing factor } \\
\hline & Age 3 & Age 5 & Age 6.5 & Age 8-9 & Age 3 & Age 5 & Age 6.5 & Age 8-9 \\
\hline $\operatorname{Sex}^{\wedge}$ & $-0.11(0.02)$ & $-0.13(0.03)$ & $-0.11(0.04)$ & $-0.15(0.04)$ & $0.04(0.02)$ & $0.03(0.03)$ & $0.1(0.04)$ & $0.05(0.04)$ \\
\hline Cognitive ability & $-0.07(0.03)$ & $-0.06(0.04)$ & $-0.06(0.04)$ & $-0.03(0.04)$ & $0.03(0.03)$ & $-0.04(0.04)$ & $-0.03(0.04)$ & $-0.02(0.05)$ \\
\hline Extraversion & $0.04(0.04)$ & $0.09(0.04)$ & $0.09(0.05)$ & $0.12(0.04)$ & $-0.05(0.03)$ & $-0.08(0.04)$ & $-0.1(0.05)$ & $-0.13(0.05)$ \\
\hline Agreeableness & $-0.04(0.04)$ & $-0.09(0.04)$ & $-0.17(0.05)$ & $-0.17(0.05)$ & $-0.03(0.03)$ & $0.04(0.04)$ & $-0.01(0.04)$ & $0.02(0.05)$ \\
\hline Conscientiousness & $0.01(0.03)$ & $-0.02(0.04)$ & $-0.09(0.05)$ & $-0.09(0.04)$ & $-0.01(0.03)$ & $0.03(0.04)$ & $0.02(0.04)$ & $0.02(0.04)$ \\
\hline Neuroticism & $0.05(0.04)$ & $0.1(0.04)$ & $0.1(0.05)$ & $0.1(0.05)$ & $0.07(0.03)$ & $0.09(0.04)$ & $0.08(0.05)$ & $0.13(0.05)$ \\
\hline Openness & $0.03(0.03)$ & $0.07(0.04)$ & $-0.02(0.05)$ & $0.02(0.05)$ & $-0.05(0.03)$ & $-0.04(0.04)$ & $-0.03(0.05)$ & $0.06(0.05)$ \\
\hline
\end{tabular}

Table 1. Continued.

\begin{tabular}{|c|c|c|c|c|}
\hline & \multicolumn{4}{|c|}{ Externalizing factor } \\
\hline & Age 3 & Age 5 & Age 6.5 & Age 8-9 \\
\hline $\operatorname{Sex}^{\wedge}$ & $-0.13(0.02)$ & $-0.12(0.03)$ & $-0.11(0.04)$ & $-0.09(0.04)$ \\
\hline Cognitive ability & $-0.08(0.03)$ & $-0.15(0.04)$ & $-0.17(0.04)$ & $-0.24(0.05)$ \\
\hline Extraversion & $0.09(0.03)$ & $0.03(0.04)$ & $0.09(0.05)$ & $0.04(0.05)$ \\
\hline Agreeableness & $-0.06(0.03)$ & $-0.03(0.04)$ & $-0.04(0.04)$ & $-0.03(0.04)$ \\
\hline Conscientiousness & $-0.04(0.03)$ & $-0.06(0.04)$ & $-0.14(0.05)$ & $-0.16(0.04)$ \\
\hline Neuroticism & $0.02(0.03)$ & $0.01(0.04)$ & $0.01(0.04)$ & $0.03(0.04)$ \\
\hline Openness & $0.02(0.03)$ & $0.05(0.04)$ & $-0.05(0.04)$ & $-0.02(0.04)$ \\
\hline
\end{tabular}

Note. Cognitive ability, as assessed at age 6.5, and personality traits as assessed at age 11 as outcomes in separate generalized estimating equations models for each of the 
Table 2. Possible predictors of the psychopathology factors from early to middle childhood.

\begin{tabular}{|c|c|c|c|c|c|c|c|c|}
\hline & \multicolumn{3}{|c|}{$p$ factor } & \multirow[b]{2}{*}{ Age 8-9 } & \multirow[b]{2}{*}{ Age 3} & \multicolumn{2}{|c|}{ Internalizing factor } & \multirow[b]{2}{*}{ Age 8-9 } \\
\hline & Age 3 & Age 5 & Age 6.5 & & & Age 5 & Age 6.5 & \\
\hline Age 3 developmental problems & $0.08(0.03)$ & $0.06(0.03)$ & $0.07(0.04)$ & $0.07(0.04)$ & $0.09(0.02)$ & $0.08(0.03)$ & $0.07(0.04)$ & $0.1(0.04)$ \\
\hline Hospitalization before age 3 & $0.04(0.03)$ & $0.07(0.03)$ & $0.04(0.04)$ & $0.05(0.04)$ & $-0.03(0.03)$ & $0.03(0.03)$ & $0.08(0.04)$ & $0.01(0.04)$ \\
\hline Apgar 1 minute after birth & $0.04(0.03)$ & $-0.05(0.05)$ & $0.02(0.06)$ & $0.02(0.05)$ & $0.08(0.04)$ & $0.02(0.05)$ & $-0.06(0.07)$ & $-0.05(0.06)$ \\
\hline Apgar 5 minute after birth & $0.02(0.03)$ & $-0.03(0.04)$ & $-0.07(0.05)$ & $0.03(0.05)$ & $0.03(0.04)$ & $-0.03(0.05)$ & $-0.09(0.06)$ & $-0.03(0.05)$ \\
\hline Birth weight & $-0.06(0.03)$ & $-0.08(0.03)$ & $-0.05(0.04)$ & $-0.03(0.04)$ & $0.01(0.03)$ & $-0.09(0.03)$ & $-0.1(0.05)$ & $-0.06(0.05)$ \\
\hline Breast feeding & $-0.05(0.03)$ & $0.01(0.03)$ & $0.05(0.05)$ & $-0.09(0.05)$ & $-0.01(0.03)$ & $-0.04(0.03)$ & $0.01(0.05)$ & $0.04(0.05)$ \\
\hline Complications of pregnancy & $0.08(0.03)$ & $0.08(0.03)$ & $0.05(0.05)$ & $0.05(0.04)$ & $0.03(0.03)$ & $0.08(0.03)$ & $0.09(0.04)$ & $0.11(0.04)$ \\
\hline Hospitalization first year of life & $0.03(0.03)$ & $0.06(0.03)$ & $0.07(0.04)$ & $0.11(0.04)$ & $-0.04(0.03)$ & $0.06(0.04)$ & $0.08(0.04)$ & $0.07(0.04)$ \\
\hline Mother's Age at birth & $-0.02(0.03)$ & $0.01(0.04)$ & $-0.02(0.05)$ & $0.05(0.05)$ & $-0.03(0.03)$ & $-0.04(0.03)$ & $-0.09(0.04)$ & $-0.03(0.04)$ \\
\hline Neonatal problems & $0.06(0.03)$ & $0.11(0.03)$ & $0.08(0.04)$ & $0.09(0.04)$ & $0.01(0.03)$ & $0.07(0.03)$ & $0.08(0.04)$ & $0.04(0.04)$ \\
\hline SES at age 3 & $-0.07(0.03)$ & $-0.11(0.03)$ & $-0.09(0.04)$ & $0.01(0.05)$ & $-0.1(0.03)$ & $-0.14(0.03)$ & $-0.07(0.04)$ & $-0.11(0.04)$ \\
\hline Weeks of pregnancy & $-0.04(0.03)$ & $-0.05(0.03)$ & $0.01(0.05)$ & $0.02(0.04)$ & $-0.03(0.03)$ & $-0.09(0.03)$ & $-0.11(0.04)$ & $-0.05(0.05)$ \\
\hline
\end{tabular}


Table 2. Continued.

\begin{tabular}{|c|c|c|c|c|}
\hline & \multicolumn{4}{|c|}{ Externalizing factor } \\
\hline & Age 3 & Age 5 & Age 6.5 & Age 8-9 \\
\hline Age 3 developmental problems & $0.1(0.03)$ & $0.09(0.03)$ & $0.11(0.04)$ & $0.11(0.04)$ \\
\hline Hospitalization before age 3 & $0.06(0.03)$ & $0.08(0.03)$ & $0.12(0.04)$ & $0.1(0.04)$ \\
\hline Apgar 1 minute after birth & $-0.03(0.04)$ & $-0.06(0.05)$ & $-0.06(0.06)$ & $0.05(0.05)$ \\
\hline Apgar 5 minute after birth & $0.06(0.03)$ & $0.01(0.05)$ & $0.01(0.05)$ & $0.1(0.04)$ \\
\hline Birth weight & $-0.09(0.03)$ & $-0.08(0.03)$ & $-0.1(0.04)$ & $-0.08(0.05)$ \\
\hline Breast feeding & $-0.03(0.03)$ & $0.02(0.03)$ & $0.03(0.05)$ & $0.01(0.04)$ \\
\hline Complications of pregnancy & $0.06(0.02)$ & $0.05(0.03)$ & $-0.05(0.04)$ & $-0.03(0.04)$ \\
\hline Hospitalization first year of life & $0.03(0.03)$ & $0.04(0.03)$ & $0.07(0.04)$ & $0.11(0.04)$ \\
\hline Mother's Age at birth & $-0.06(0.03)$ & $-0.08(0.03)$ & $-0.03(0.05)$ & $0.01(0.04)$ \\
\hline Neonatal problems & $0.07(0.03)$ & $0.02(0.03)$ & $0.09(0.04)$ & $0.06(0.04)$ \\
\hline SES at age 3 & $0.02(0.02)$ & $-0.04(0.03)$ & $-0.03(0.04)$ & $0.01(0.04)$ \\
\hline Weeks of pregnancy & $-0.05(0.03)$ & $-0.05(0.03)$ & $-0.09(0.04)$ & $-0.05(0.05)$ \\
\hline
\end{tabular}

Weeks of pregnancy

Note. The factors as outcomes in separate generalized estimating equation models for each of the predictors and waves. Sex (coded as $1=$ males, $2=$ female), age, and SES from age 3 were used as covariates in all analyses (in the SES as variable of interest models sex and age were entered as covariates). Coefficients significant at p<.01 are in bold font. 
836 Figure 1. Psychopathology factors correlations.

837 1A. Correlations between the $p$, internalizing (INT), and

838 externalizing (EXT) factors from early- to mid-childhood (for one twin 839 per family).

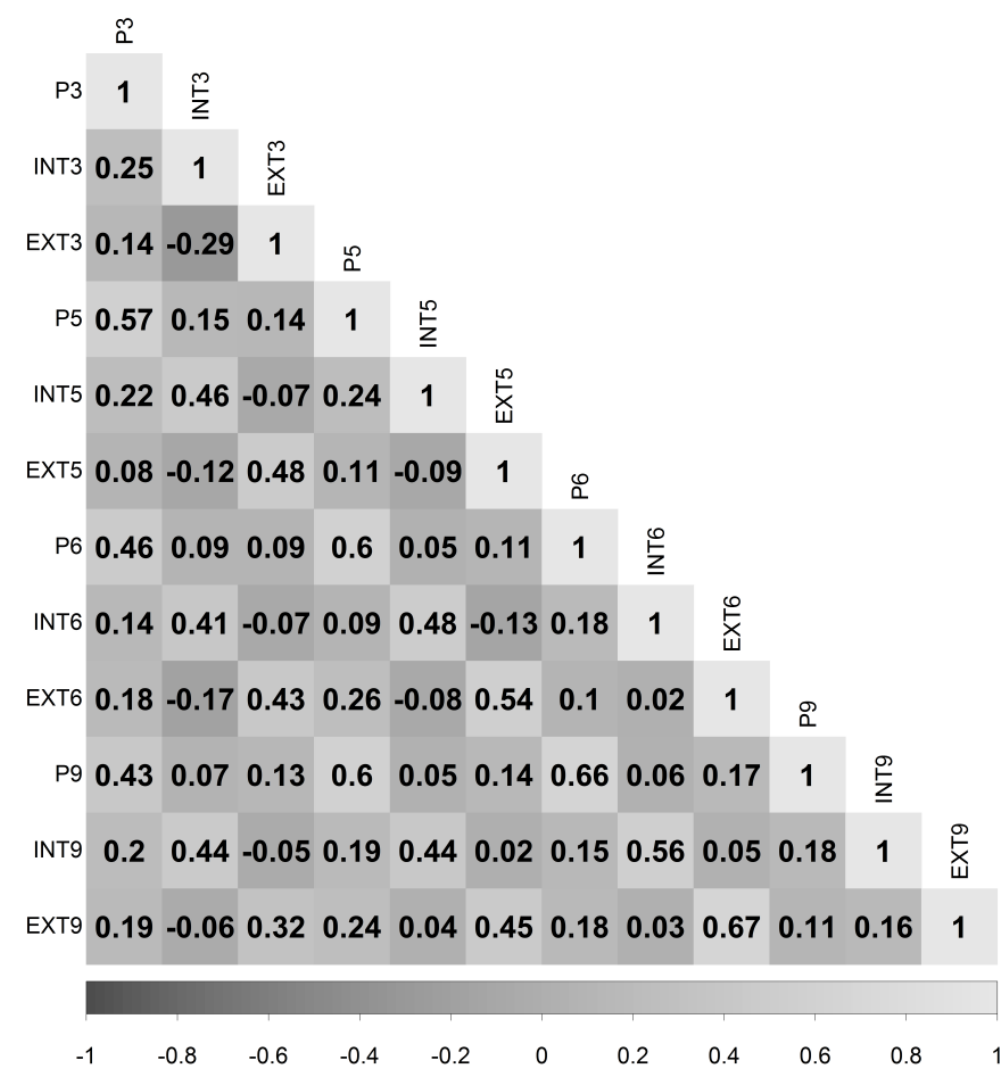

1B. Twin correlations and $95 \%$ confidence intervals for psychopathology factors from early- to mid- childhood.

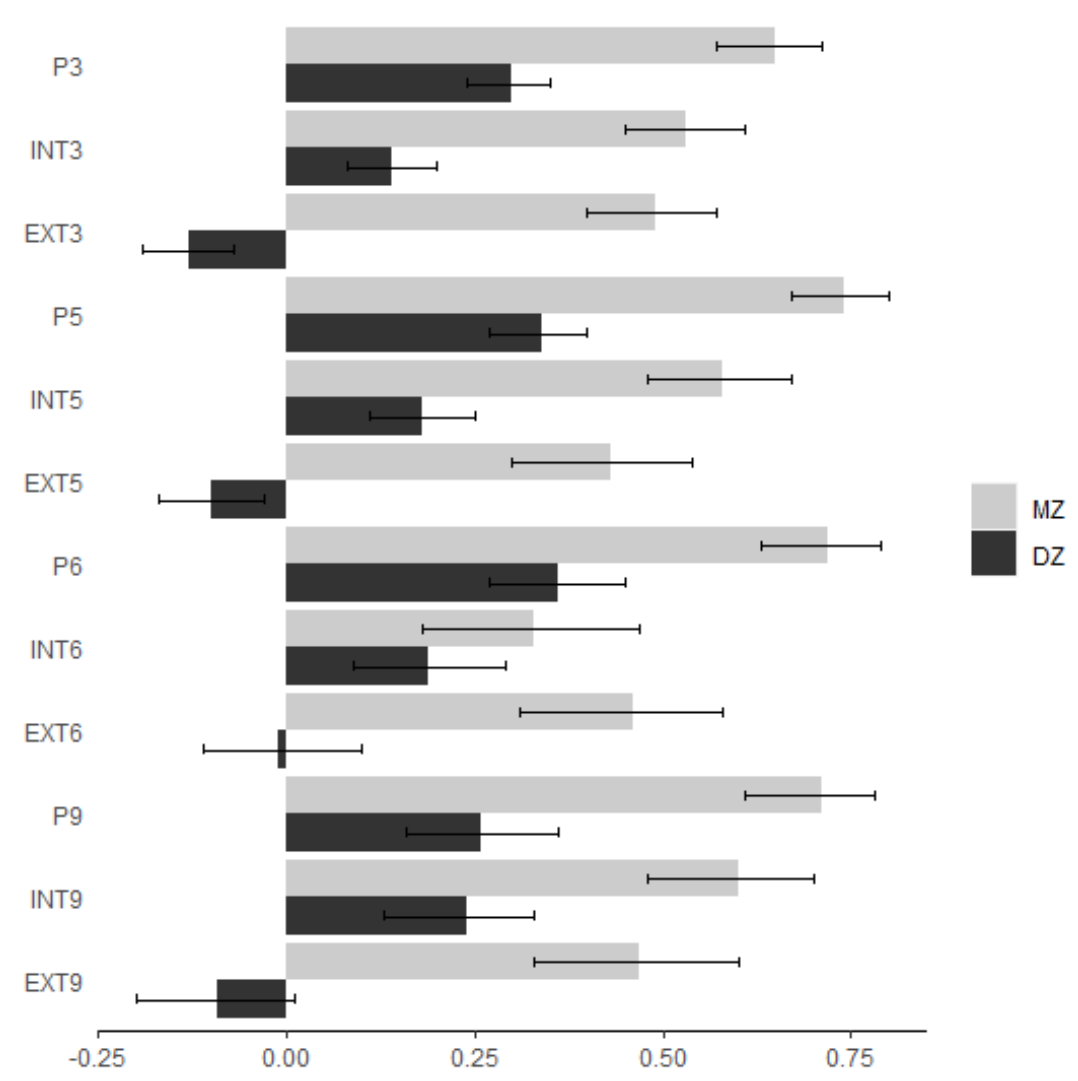


841

842 Figure 2. A longitudinal twin model. Genetic and environmental influences on psychopathology factors, from early to middle childhood.

A. The $p$ factor, AE model.

8

8

846

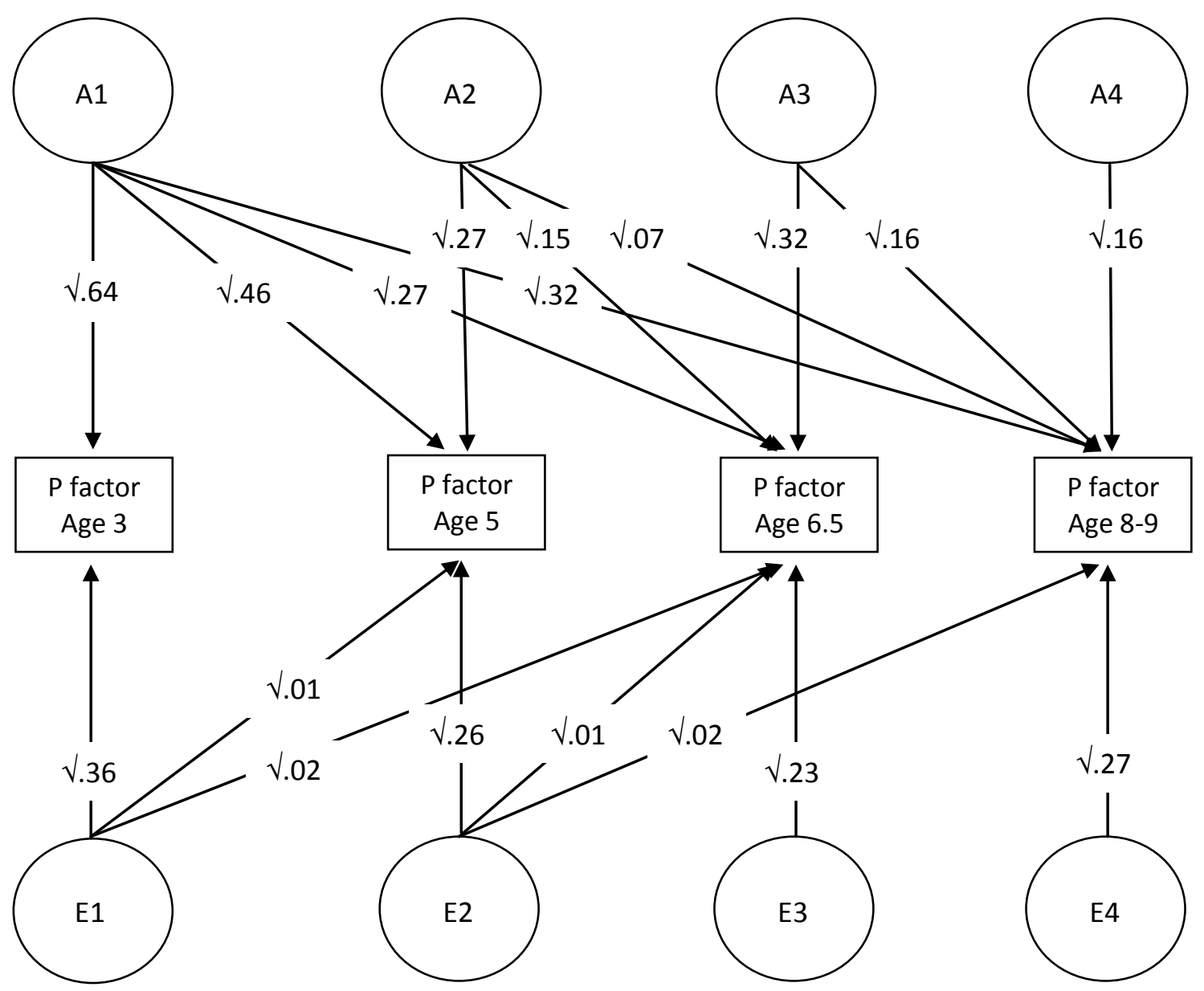


B. The specific/residualized externalizing factor, ACE model with contrast effect (not shown).

848

849

850

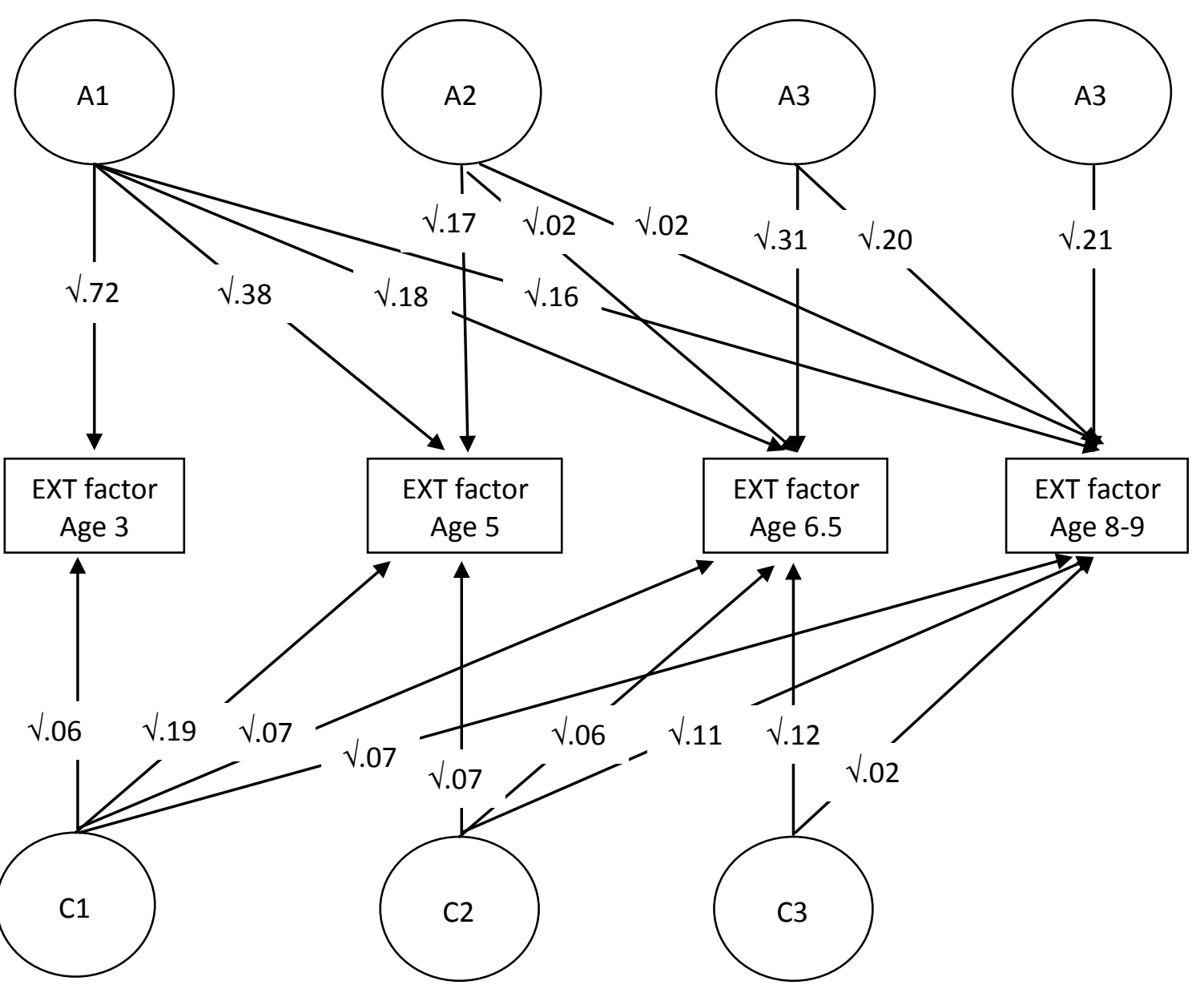


851 B. continued. The externalizing factor.

852

853

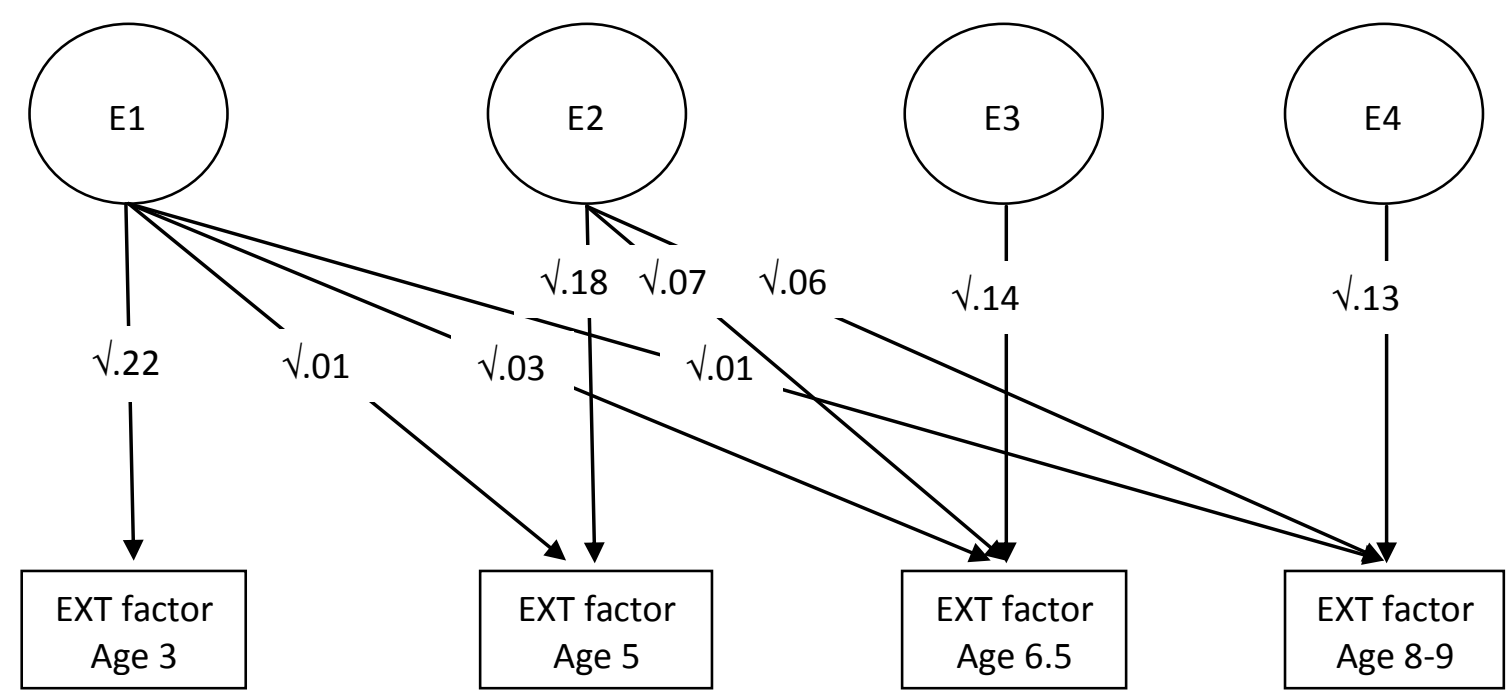


855

856

857

858

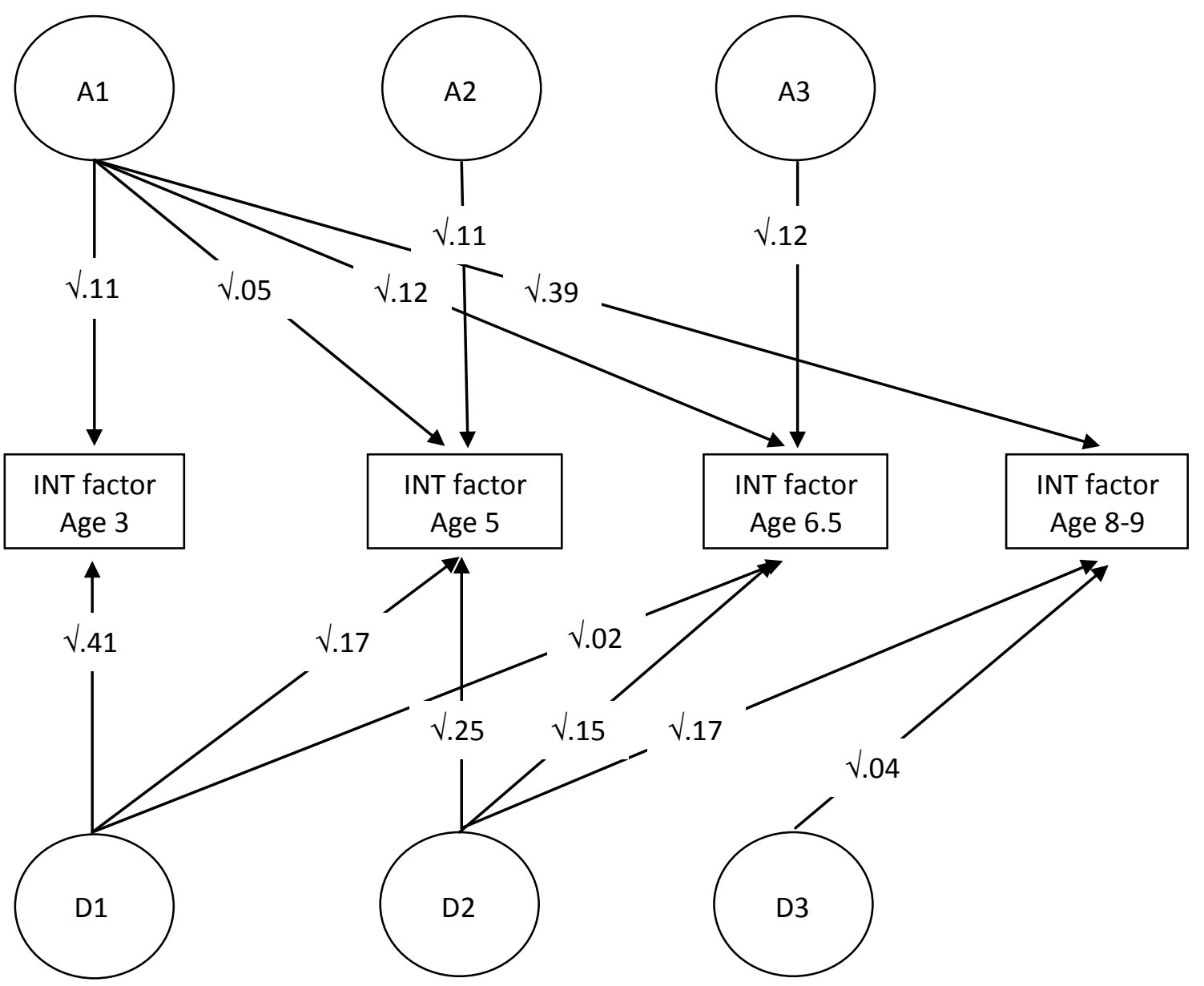


C. continued. The specific/residualized internalizing factor.

860

861

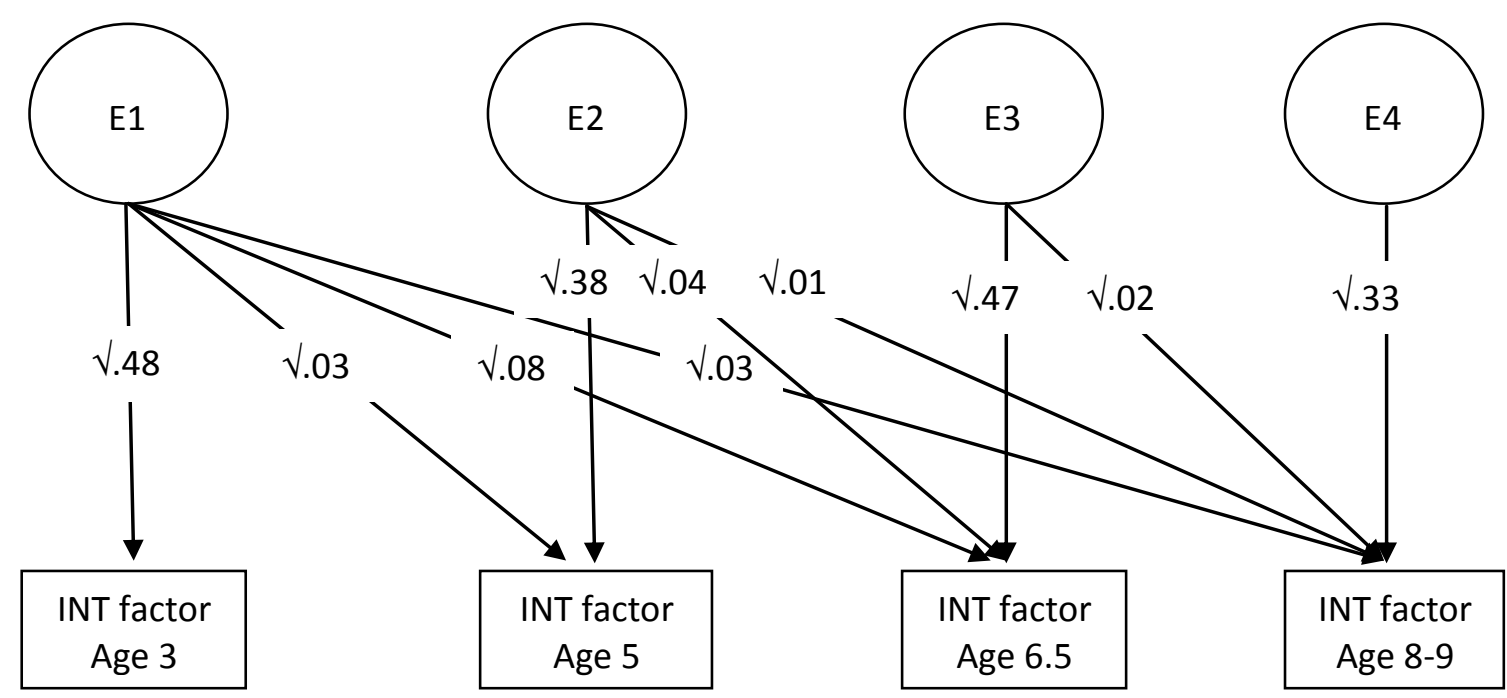

862 
Figure 3. The psychopathology factors as predictors of developmental problems, self-esteem, and well-being, including error bars.
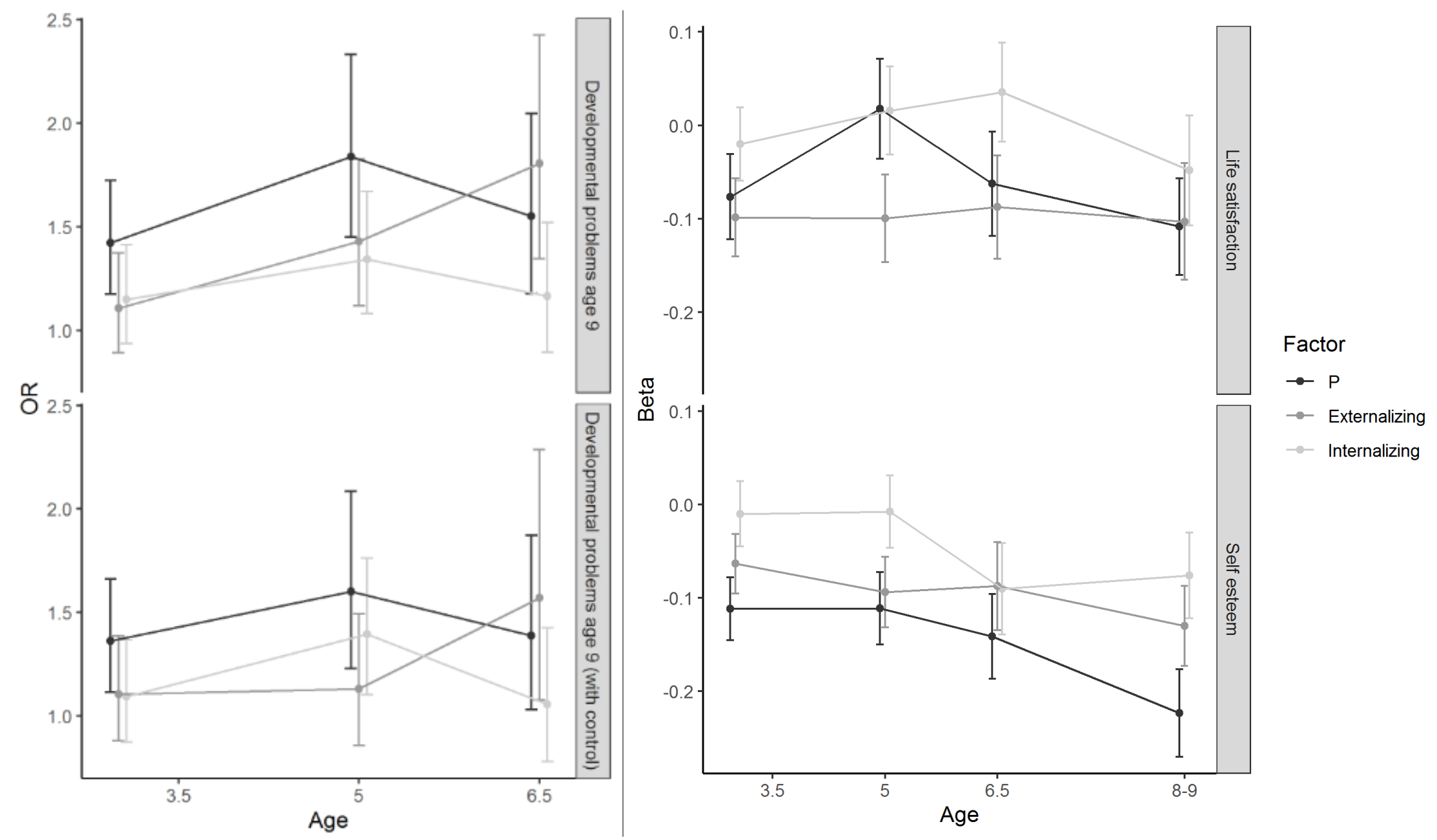
865 Note. In all models age, sex (coded as 1=males, 2-female), and socioeconomic status as assessed at age 3 were entered as covariates. Results of generalized estimating equation models are presented. All models are independent (i.e., each factor was examined as a predictor in an independent statistical model). The model "with control" also included a developmental problems (yes/no) measure, assessed at the same age as the tested factor, as a covariate. Error bars are based on the standard errors. 